\title{
EM PARALELO - UMA HIPÓTESE PARA O SÉCULO XXI Ocupação do espaço aéreo como alternativa de adensamento e preservação do tecido urbano
}

\section{PARALLEL - AN HYPOTHESIS FOR THE 21st CENTURY Occupying the air space as a density alternative and the preservation of urban tissue}

\author{
A. Maurício Addor Neto \\ Universidade Presbiteriana Mackenzie, Brasil \\ addor.arq@gmail.com
}

\begin{abstract}
RESUMO
Este ensaio visa fomentar a discussão de novas alternativas de conceber as metrópoles para o século XXI, uma vez que as transformações culturais e tecnológicas alteram o espaço e as definições que pautaram o desenvolvimento urbano ao longo do século XX podem não mais ser tão eficientes. Há a necessidade de adensar e transformar as metrópoles, ao mesmo tempo que sua preservação também é desejada. Para lidar com essa condição ambígua, novas alternativas terão que ser idealizadas, uma vez que as transformações ocorrerão, sejam elas planejadas ou não. Uma das possíveis alternativas para lidar com esse futuro seja através da ocupação do espaço aéreo, com a criação de uma malha urbana tridimensional, visando o adensamento e simultaneamente a preservação do tecido consolidado na cota térrea.
\end{abstract}

Palavras-chave: Adensamento, Espaço Aéreo, Metrópole, Transformação urbana.

Linha de Investigação: 1: Cidade e projeto

Tópico: Morfologia Urbana

\begin{abstract}
This essay aims to encourage the discussion of new alternatives to conceive the metropolises for the 21 st century, since the cultural and technological transformations alter the space and the definitions that guided the urban development throughout the 20th century may no longer be as efficient. There is a need to densify and transform the metropolises, while their preservation is also desired. To deal with this ambiguous condition, new alternatives will have to be devised, since the transformations will occur, whether they are planned or not. One of the possible alternatives to deal with this future is through the occupation of air space, with the creation of a three-dimensional urban network, aiming the densification and simultaneously the preservation of the consolidated urban fabric at the ground level.
\end{abstract}

Keywords: Density, Air space, Metropolis, Urban transformation

Research line: 1: City and Project

Topic: Urban Morphology 


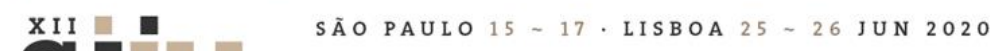

\section{Introdução}

O presente trabalho tem como objetivo flertar com as possibilidades de ocupação territorial da metrópole. O fator de constante mudança cultural e tecnológica, inerente à sociedade contemporânea de uma cidade de caráter global, está indissociável à construção espacial. As consequências das transformações por vezes somente são percebidas após tais mudanças ocorrerem. Para refletirmos o que podem vir a ser as metrópoles do século XXI, talvez seja necessário repensar os mecanismos analíticos e projetuais, evoluindo as pautas do século passado para conceber a cidade do futuro, que já é presente.

A metrópole paulistana se formou ao longo do século XX em uma expansão territorial sem limites, inflando-se horizontalmente conforme seu número de usuários e habitantes cresciam exponencialmente. Com a necessidade de ser adensada, seu tecido urbano foi alterado, criando cada vez mais distintas paisagens, porém nem sempre em harmonia com suas pré-existências.

Através desta perspectiva, podem surgir várias hipóteses de ocupação territorial. Procura-se aqui uma alternativa ao mecanismo tradicional de edificação da metrópole, cujo método se dá através da busca, compra, desapropriação, demolição e por fim, a construção. Um possível meio de enfrentar esta situação seja, conceitualmente, através da sobreposição das necessidades de adensar e preservar; e fisicamente, através da ocupação do espaço aéreo sobre o tecido consolidado. (Fig. 01)

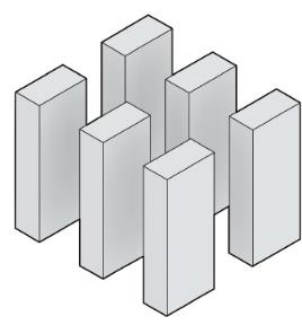

adensar

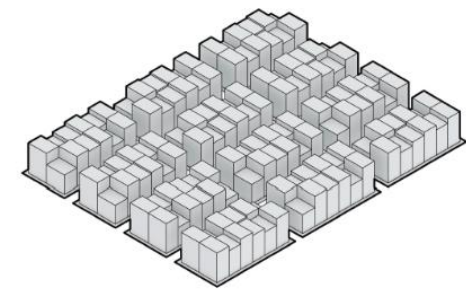

preservar

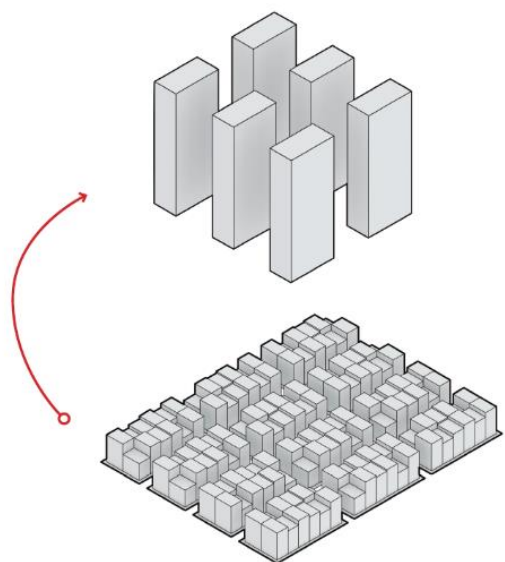

Fig. 01 Diagrama do paradoxo contemporâneo e hipótese futura. Elaboração própria.

\section{A Metrópole}

As culturas de concepção urbana são inúmeras, muito por consequência dos experimentos do século XX, onde na prática surgiram desde Manhattan até Brasília, e na teoria, desde Ville Radieuse até a Plug-In City. Um verdadeiro laboratório de utopias construídas e não construídas, em que a tecnologia foi surgindo cada vez mais como principal fator inerente à urbanidade. 


\section{SÃO PAULO15 $17 \cdot$ LISBOA $25 \sim 26$ JUN 2020}

As concepções urbanas e planos que pautaram o desenvolvimento da metrópole ao longo do século XX derivam de uma condição muito especial em que a humanidade estava inserida no início da era moderna e vanguardista do século $\mathrm{XX}$.

\subsection{Contexto vanguardista}

A mudança de posição e responsabilidade do homem como indivíduo na sociedade ao longo dos três últimos séculos foi culturalmente reivindicada e definida, traduzindo em novas possibilidades de ocupar a cidade. Espaços para fomentar a discussão começaram a ser imaginados. Experiências diversas surgem ao redor do globo, abrigando essa nova cultura, sendo principalmente um produto do contexto político-econômico em que estão inseridas.

No contexto soviético, surgiram os construtivistas e os condensadores sociais, com um projeto de futuro utópico no qual a urbe era a resposta para todas as mazelas da sociedade (Yoos, James, 2016). No contexto capitalista, (leia-se aqui manhattanista), surgia os arranha-céus e um projeto de futuro progressista no qual tudo é possível se gerenciado pelo livre fluxo do capital (Koolhas, 1972).

As cidades passaram a receber um outro tipo de atenção e planos de modernização começaram a surgir em todo mundo. Um dos mais famosos foi a transformação de Paris por Georges-Eugène Haussmann, em 1853. Nele, parte do tecido urbano foi redesenhado, atendendo aos tempos modernos.

Esse projeto foi o gatilho para encorajar mais arquitetos e urbanistas a imaginarem a cidade ideal. Henri Jules Borie, concebe volumes maciços de 10 andares como habitação coletiva em "Aérodromes"; JulesAntoine Moilin, em contraste a Paris de Haussmann, imagina em seu livro "Paris nos anos 2000", uma malha peatonal elevada, sobrepondo-se a toda cidade velha; Eugène Hénard desenha uma via de serviços totalmente subterrânea em "Cidades do Futuro". Não muito divergente, mais tarde com Charles-Édouard Jeanneret, ou Le Corbusier, é concebido o "Plan Voisin" (Yoos, James, 2016).

Já em Nova lorque, esse futuro possível, passou também a ter uma imagem. A utopia era o adensamento extremo, aliando empreendimentos imobiliários à tecnologia e ao capital. Foram criadas cidades multiníveis, em constante movimento, organizadas pela intensidade do tráfego, no qual a infraestrutura molda o meio urbano.

Em 1900, Moses King publica "King's Dream of New York". Harvey Wiley Corbett, com um desenho, exemplifica como seria esse adensamento de Manhattan por camadas em "The City You May Live to See". Hugh Ferris, idealiza a Manhattan do futuro em "The Metropolis of Tomorrow", no qual vias elevadas de pedestres e de automóveis se apoiam nos recuos dos arranha-céus, definidos pelo Zoneamento de 1916. No mesmo ano, Raymond Hood publica "Manhattan of 1950", no qual as pontes que conectam a ilha aos outros distritos são ocupadas com edificações de elevadíssimos gabaritos e uso misto, unificando arquitetura e infraestrutura em uma simbiose metropolitana (Koolhas, 1972; Yoos, James, 2016). 


\section{SÃO PAULO15 17 LISBOA $25 \sim 26$ JUN 2020}

\subsection{Os Situacionistas e as utopias pós-modernas}

O período pós-guerra dos anos 1950 a 1970 testemunhou uma transformação no imaginário da sociedade advindas com o estado do bem-estar social e dos avanços tecnológicos da época, gerando uma nova era de otimismo que demandava novas cidades para um cidadão global (Ribeiro, 2017).

Em um primeiro momento, pode-se destacar Constant Nieuwenhuis em New Babylon (1959), onde toda porção do edifício é desprendida do solo, apoiada em pilares, e sobre ela, há a circulação de veículos.

Posteriormente, do outro lado do globo, surgia o Metabolismo, movimento que convergia o contexto físico e geográfico do Japão com o entendimento de que as megaestruturas seriam na verdade uma parte do processo de urbanização inerente a sociedade (Yoos, James, 2016). Seus maiores expoentes eram Kenzo Tange e Arata Isozaki.

A partir da década de 1960, o urbanismo moderno, defendido pelas conferências internacionais do CIAM, já mostrava sinais de colapso, juntamente com o comprometimento social auto-atribuído à arquitetura do movimento moderno. Além dos situacionistas, houve outros autores propondo uma reflexão sobre o traço prometeico e o endeusamento do arquiteto moderno, como Jane Jacobs em seu livro The Death and Life of Great American Cities, de 1961, e Bernard Rudofsky, que por meio de sua exposição sediada no MoMA em 1964, intitulada Architecture Without Architects, chamou a atenção para a reconsideração das particularidades locais e valorização da arquitetura vernacular.

$\mathrm{Na}$ virada da década de 60 para 70 é que as utopias urbanas se transformam em distopias, cujas melhores representações se encontram no Monumento Contínuo do grupo italiano Superstudio, que posteriormente evoluiria para As Doze Cidades Ideais, e também com Rem Koolhas, Elia Zenghelis, Zoe Zenghelis e Madelon Vreisendrop em Exodus.

\subsection{O novo milênio}

$\mathrm{Na}$ virada para o Século XXI, a principal crise era a da falta de sustentabilidade. Há um despertar global sobre como construímos nossas cidades, que então, tornaram-se alvos de investigação. A dispersão urbana causada pelos modelos rodoviaristas desenvolvidos no século XX mostraram-se inviáveis. Esse modelo de cidade gerou bairros residenciais distantes, conectados entre si e com o centro através de vias expressas destinadas ao automóvel particular que rasgaram o tecido urbano, fragmentando-o por zonas com funções distintas. (Rogers, 2016).

\subsubsection{O adensamento}

Um outro modelo surge como resposta à expansão horizontal: a cidade compacta. Para poder absorver o crescimento e expansão urbana com sustentabilidade, a cidade precisa voltar para si. O planejamento urbano agora é uma disciplina holística e abrangente, envolvendo ecologia, economia e sociologia (Rogers, 2016). 


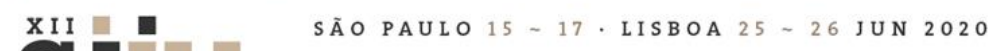

Em uma cidade compacta, quem comanda é a densidade construtiva, populacional, programática e funcional. No âmbito urbanístico, é um maior número de pessoas morando na mesma região, usufruindo de infraestruturas urbanas e equipamentos públicos próximos, gerando uma sobreposição de atividades econômicas, culturais e sociais, promovendo a multifuncionalidade, com uma estrutura flexível e um forte noção de comunidade. (Per, Mozas, Arpa, 2015)

Em São Paulo, o adensamento ocorreu às custas dos espaços públicos e da vitalidade dos mesmos. Há uma elevada concentração de infraestrutura em seu centro histórico, seja lazer, serviços, transportes e negócios, que em grande parte, é usufruída por uma população que lá não reside. Esse processo gera uma dinâmica denominada movimento pendular, onde uma massa populacional se desloca por grandes extensões, diariamente, vivenciando a cidade em retalhos e fragmentos, e não como um espaço fluido e contínuo (Moura, Branco, Firkowski, 2005).

A população estimada de São Paulo em 2018 foi de 12.178 .866 habitantes (IBGE), sendo que na região da Sé, a população chega a 431.106, e no centro expandido - zona delimitada pelos anéis viários dos Rios Pinheiros e Tietê, há cerca de 2.102.851 habitantes. Portanto, são mais de 10 milhões de pessoas que não possuem as mesmas qualidades e facilidades urbanas que a região oferece.

Com o objetivo de atender a demanda, edifícios são construídos aos moldes tradicionais do mercado imobiliário, demolindo as pré-existências e levantando espigões sem valor arquitetônico e urbanístico, sem relação com a cidade, fechados em si mesmos, intensificando apenas a vida privada, gerando cada vez mais uma cidade segregada, uma cidade de pontos (Correa, 2018).

\subsubsection{A preservação}

Como palco de transformação social e cultural, a cidade contemporânea é melhor definida como um palimpsesto, que se sobrescreve a cada instante, acrescentando distintas camadas ao longo do tempo (Toledo, 1981).

Há de se pensar a cidade como memória e saber identificar as condicionantes urbanas que trazem identidade e noção de pertencimento à região, juntamente dos elementos que a caracterizam. O conceito de preservação e patrimônio pode, inclusive, estender-se à fisionomia da cidade como um todo. Como Marisa Barda evidencia em seu livro Espaço (Meta)Vernacular na Cidade Contemporânea (2009), essa lógica tem a finalidade de gerar uma nova postura nas intervenções urbanas, cujo tecido deve ser considerado como referência para as transformações futuras.

Outro fator importante para a metrópole é sua malha e consequente morfologia urbana. Leslie Martin em seu texto The Grid as Generator (1972), evidencia o traçado como gerador e possuidor de todas dinâmicas urbanas.

\subsubsection{A hipótese}

Um caminho para enfrentar tal dilema seja talvez através da sobreposição de necessidades. A metrópole já funciona em camadas - há a camada das edificações, espelho do contexto geográfico, cultural e econômico 


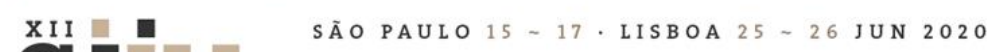

em que se insere, e pelo qual o verdadeiro abrigo do ser humano ocorre. Em seguida, a camada da malha urbana, que caracteriza e define todas dinâmicas objetivas e subjetivas das edificações, é definida como espaço público por excelência, totalmente apropriável e flexível, local para manifestação cultural e social de seus habitantes. E por último, porém não menos importante, na realidade essencial para as demandas da metrópole, há o metrô, elemento conector e difusor das massas, encontrado sob o tecido, que articula e possibilita as funções da cidade contemporânea.

E se houvesse uma camada extra (Fig. 02)? Uma superestrutura, que se sobrepusesse sobre todo este contexto através de eliminações específicas, compreendendo a característica energética da metrópole, abrigando uma série de atividades distintas em um programa complexo, digno da intenção de se construir numa cidade global, preservando as dinâmicas sociais definidas pelas outras três camadas, porém atendendo a uma demanda que talvez não consiga encontrar espaço nas mesmas - o adensamento (Fig. 03).

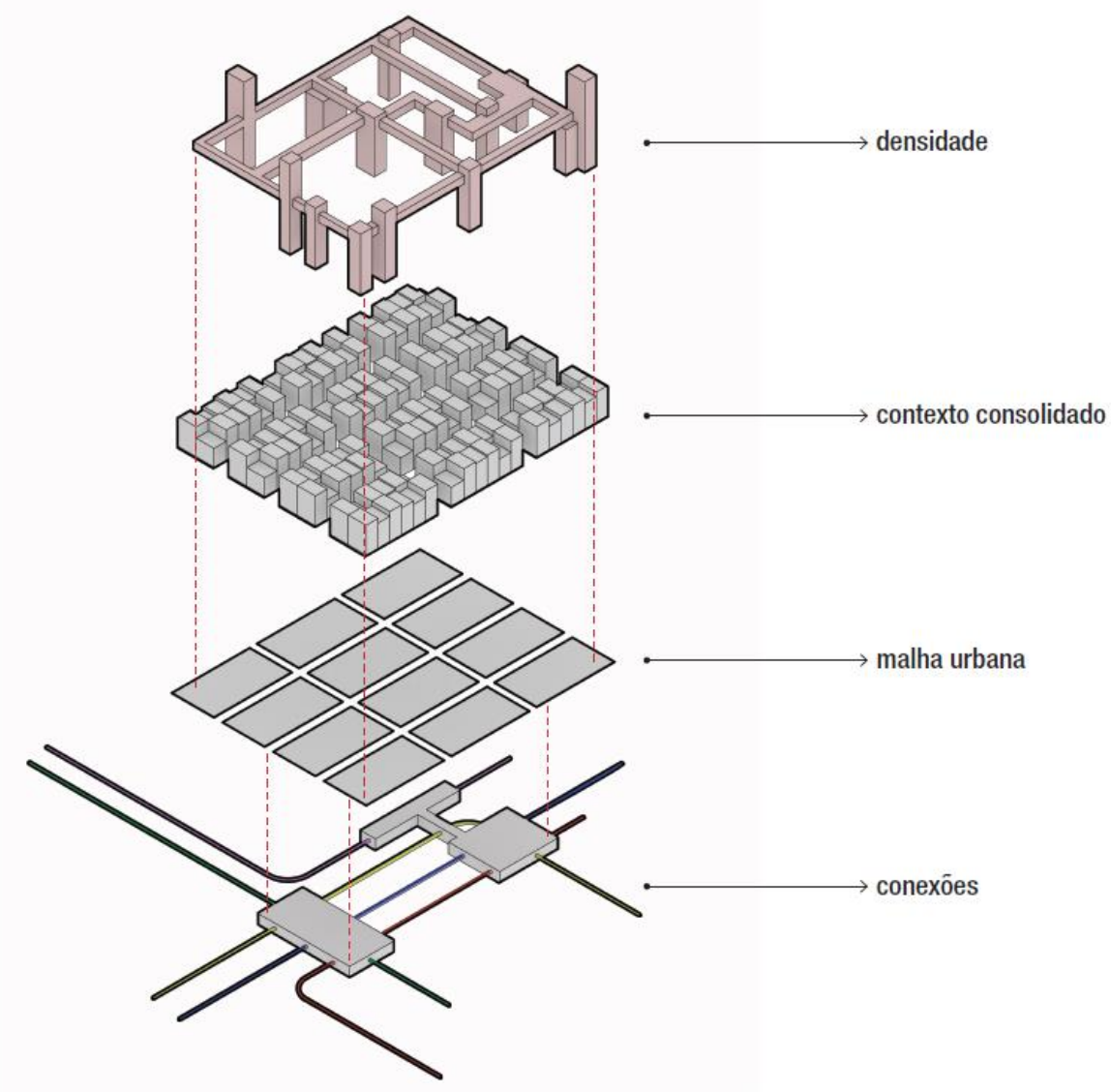

Fig. 02 Axonométrica explodida das camadas metropolitanas. Elaboração própria. 


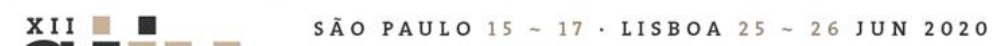

Seminário Internacional de Investigação em Urbanismo

Seminario Internacional de Investigación en Urbanismo

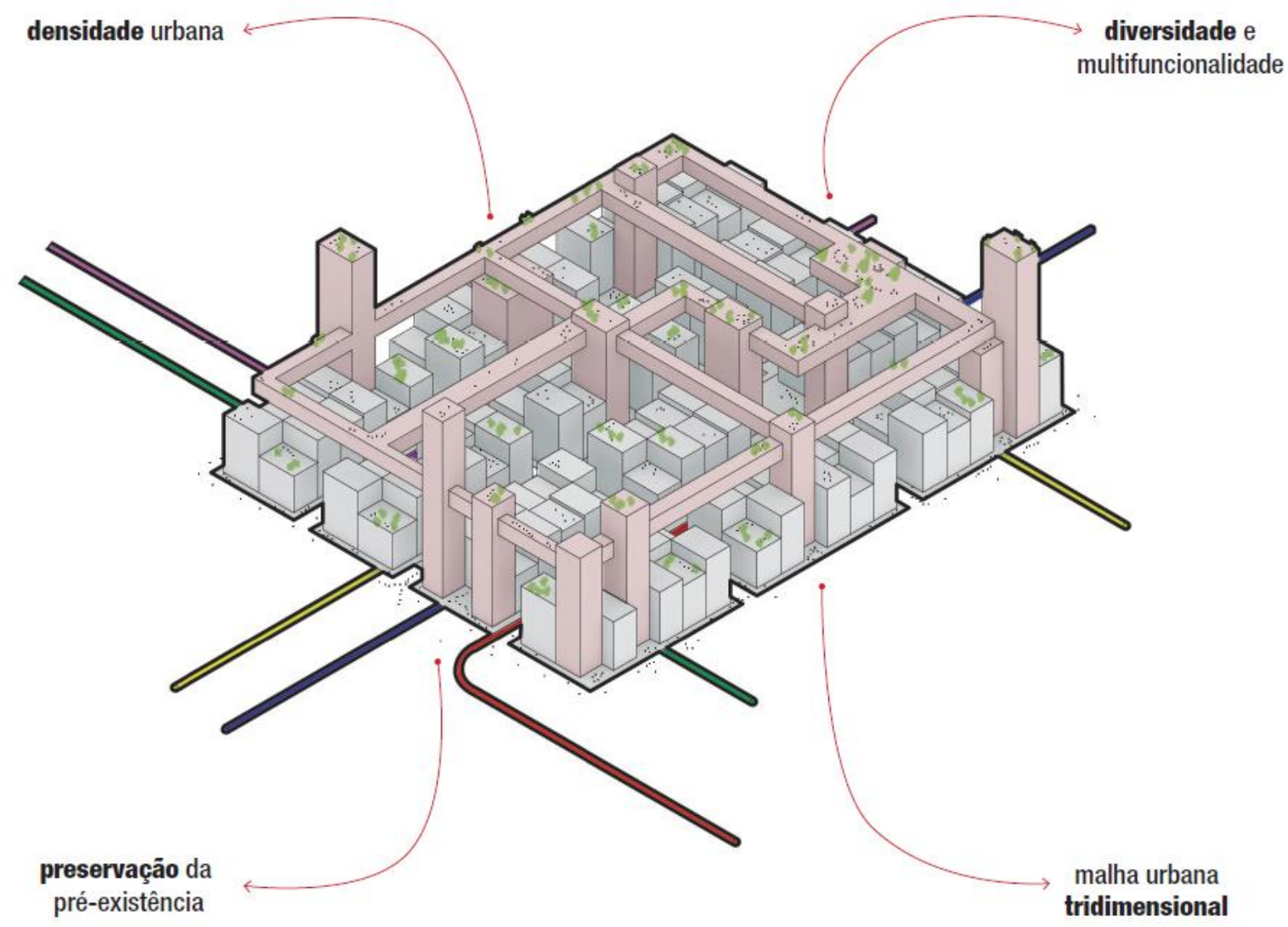

Fig. 03 Axonométrica da malha urbana tridimensional. Elaboração própria.

\section{0 Contexto}

A escolha das quatro regiões para este estudo - Sé, República, Santa Ifigênia e Campos Elíseos, se dá pelo fato de constituírem os tecidos urbanos mais resilientes. É neles que se encontram as construções mais antigas, amplo acesso ao transporte e aos equipamentos públicos. Todos sendo elementos que configuram a memória e a paisagem urbana paulistana. Apesar da origem da cidade remontar ao século XVI, sua maior parte foi construída nos últimos cento e trinta anos. As áreas em questão testemunharam essa evolução urbana e fizeram parte dela.

Há um levantamento integral de dados territoriais assistido por softwares de geoprocessamento, e posterior comparação, a fim de melhor compreender um possível local para desenvolvimento do conceito (Fig. 04). 



\section{SÃOPAULO15 $\quad 17 \cdot$ LISBOA $25 \sim 26$ JUN 2020}

A volumetria e tipologia de seus edifícios remonta a época e legislação de suas construções. São edifícios sem recuos laterais, ocupando grande porção do lote, gerando poucos resíduos urbanos. Os vazios são concentrados em locais específicos, como a Praça da Sé, e o Palácio da Justiça. O gabarito médio não é elevado, há uma série de construções de 2 a 4 pavimentos, principalmente na porção sul, mais próxima ao bairro da Liberdade.

Quando comparado densidade construtiva e demográfica, percebe-se uma divergência. A região de elevado gabarito, à noroeste, possui uma menor presença populacional se comparado a região mais ao sul, de menor gabarito. Ou seja, há uma concentração construtiva que não se equipara com a concentração demográfica. Isso se dá devido aos tipos de usos que ocorrem nesses edifícios, em sua maioria serviços e comércio; isso proporciona uma cidade ativa e informal durante o dia, porém uma outra no período noturno, vazia e sem ocupação urbana. Condição esta que embasa o argumento do movimento pendular e da baixa densidade na região central.

\subsection{República}

A região da República configura-se já como "Centro Novo", apelido dado as áreas ocupadas na época que se localizavam além do vale do Anhangabaú, cujo vão fora vencido e a conexão estabelecida através do Viaduto do Chá, construído em 1888. Aqui já há um desenho relativamente mais claro, nos quadrantes noroeste e sudeste. Neste último, porém, as vias são exclusivas ao tráfego de pedestres. Por consequência, há também um elevado número de vias caracterizadas como eixos urbanos, principalmente a Avenida Ipiranga, que corta a região pelo meio.

Esse eixo já conta com uma calha maior para o tráfego de automóveis, devido a sua importante função de conectar o "Centro Velho" ao um outro tipo de centro, o comercial e empresarial, localizado na região da Avenida Paulista, pela Rua da Consolação. Outro importante eixo é o da Avenida São João, conectando mais uma vez o Centro Velho à toda porção noroeste do centro expandido, como a Barra Funda, e posteriormente a Perdizes, Pompéia e Água Branca, quando vira avenida Francisco Matarazzo.

A volumetria das edificações do bairro é de certa maneira regular; edifícios ocupam a maior parte do lote como a Sé, principalmente onde há vias exclusivas à pedestres. Semelhante aos moldes europeus, porém sem o miolo de quadra como articulador urbano. Os vazios urbanos na República quase não existem, configurando-se apenas em praças junto à edifícios de caráter institucional, como a Praça da República e o prédio Caetano de Campos, que hoje é a sede da Secretaria de Educação do Estado, a Praça Dom José Gaspar em conjunto com a biblioteca Mário de Andrade, e a Praça Ramos de Azevedo, com a o Theatro Municipal de São Paulo, que serve como conexão com a cota inferior do Vale do Anhangabaú.

Portanto, para incrementar o percurso do pedestre, uma série de edifícios possuem fruição pública e comportam-se como galerias, conectando vias distintas, como a Galeria Metrópole, Praça das Artes, Sesc 24 de maio, Conjunto Zarvos e Copan. Nesse caso é um ótimo exemplo de uma boa relação do edifício e malha urbana.

A densidade construtiva na República é bem elevada, as edificações possuem elevado gabarito, com uma média de 10 a 15 pavimentos. Nela se encontram também os clássicos da arquitetura moderna brasileira 


\section{SÃOPAULO15 $\quad 17 \cdot$ LISBOA $25 \sim 26$ JUN 2020}

como o edifício Circolo Italiano do arquiteto Franz Heep, de 1960, com 46 andares de uso comercial e de serviços e o Copan, de Oscar Niemeyer, cujo ano de início de construção é de 1952 e sua inauguração é de 1966, sendo esse um dos projetos mais ambiciosos do século para a cidade, possuindo até seu próprio CEP.

Porém, quando comparada a densidade demográfica da República com um elevado número de construções chega-se a uma outra incoerência a encontrada na Sé. Toda área dotada da excelente fruição pública e vitalidade urbana que se assemelha aos consolidados centros europeus possui baixa densidade populacional. Essa região sofre do mesmo problema que a Sé, um número baixo de residentes integrais.

\subsection{Santa Ifigênia}

Localizada a norte da República, a Santa Ifigênia surge como um resquício, sitiada em uma geometria triangular, entre as regiões da República e Campos Elíseos, das peças de infraestrutura ferroviária, e a Avenida Tiradentes. Seu traçado, completamente regular, com quadras de tamanho homogêneo e topografia amena, proporciona familiaridade para o transeunte, mesclando-se com a malha viária de Campos Elíseos.

Proporcionalmente, possui mais vias e cruzamentos que a República e a Sé, A região possui apenas três eixos urbanos, elementos de conexão que mais dizem respeito à outras regiões do que à própria Santa Ifigênia.

Sua densidade construtiva é especialmente baixa quando comparada aos seus vizinhos, sendo suas construções, na maioria das vezes, sobrados. Morfologicamente, as edificações preenchem as quadras quase totalmente e quando comparada essa forma com a quantidade de edificações, é possível identificar, proporcionalmente, um elevado número de lotes, conferindo um número maior de usuários. Outro fato que comprova que a região é bastante usada, apesar dos baixos gabaritos e pequenas construções, é o fato de ter uma elevada densidade demográfica, com média maior que a Sé e a República.

Conclui-se que estes sobrados são de uso misto, onde o uso predominante na cota térrea é o comércio e sobre ele, uma residência. Essa mistura condiciona a região a ser uma das mais ativas comercialmente do centro da cidade, apesar de seu tamanho e volume construído. Santa Ifigênia pode ser uma pequena amostragem de que para obter uma cidade ativa, não se necessita de um alto número de construções, especialmente quando há coerência entre malha urbana, topografia, volume de construção e mistura de funções.

\subsection{Campos Elíseos}

Enfim chega-se a Campos Elíseos, a maior área das quatro, com 1.497.000 m2. Seus limites se dão a sul através da Avenida São João, que posteriormente configura-se como Santa Cecília, e ao norte pela linha ferroviária, cuja estação, Júlio Prestes, localiza-se dentro de seu domínio. Sua malha deriva do primeiro planejamento e loteamento oficial da cidade de São Paulo, idealizada por Victor Glete e Frederico Nothmann, em 1879. Sua topografia levemente acentuada dissipa-se ao longo de sua extensão.

Seu volume construído não é tão elevado como na República ou na Sé, aproximando-se mais a Santa Ifigênia, com algumas exceções. Os edifícios possuem em média 4 pavimentos, de 12 metros de altura. São 


\section{SÃOPAULO15 $\quad 17 \cdot$ LISBOA $25 \sim 26$ JUN 2020}

3.130.464 m2 de área construída, e 11.383 pavimentos. Em relação ao seu tamanho, não possui uma elevada densidade construtiva, tendo um Coeficiente de Aproveitamento médio de 2,86. Os vazios urbanos são mais frequentes na região central, próxima do cruzamento da Avenida Rio Branco e da Alameda Nothmann; e, em sua maioria, são resquícios dos lotes que contém centenários casarões, remanescentes da época da indústria cafeicultora. Há, porém, a presença de vazios como articuladores urbanos, como a Praça Princesa Isabel e Praça Júlio Prestes. Por ser uma região relativamente abrangente, possui uma variedade tipológica elevada, contendo também sobrados e edifícios modernistas e contemporâneos, sejam eles residenciais e comerciais.

Sua densidade demográfica tem uma média elevada, comparável ao da Santa Ifigênia, cujos maiores índices se encontram mais ao sul, próxima da região da Avenida São João. Isso ocorre provavelmente pois ao longo deste eixo, foram construídas uma série de edifícios residenciais, cujo perfil de usuários mudou drasticamente depois da construção do Elevado João Goulart. A região de menor densidade é aquela mais próxima da estação de trem, local onde antigamente localizava-se um terminal de ônibus. Este terminal mudou de endereço, transferindo-se ao lado da Praça Princesa Isabel, a fim de aproximar-se do principal eixo urbano, a Avenida Rio Branco. No lugar do antigo terminal, ao lado da Praça Júlio Prestes, está em curso hoje a construção de um conjunto habitacional de interesse social proveniente de uma PPP - Parceria Público Privada, cujo projeto, do escritório de arquitetura Biselli Katchborian, proporcionará um aumento nos índices demográficos.

Campos Elíseos é escolhido como o local de ensaio devido ao potencial de transformação mais elevado do que as outras regiões analisadas. Seu ambiente construído e sua morfologia são mais flexíveis que a Sé e a República, o que naturalmente atrai o mercado imobiliário. Seu traçado viário possui uma malha reticular, de escala coerente com a proposta, e uma topografia de leve variação, em contraste com a Sé, por exemplo. A região possui mais infraestrutura e conexões urbanas do que a Santa Ifigênia, apesar da similaridade do tecido urbano. Quando somados todas essas condições e se for levado em conta a quantidade de imóveis tombados sob seu contexto, conclui-se que o futuro de Campos Elíseos será um embate de entidades com inclinações preservacionistas e outras favoráveis à construção e alteração da paisagem a fim de aproveitar o momento gerado pelo interesse em habitar o centro. Em outras palavras, preservar e adensar.

\section{A Intervenção}

Foi procurado desenvolver uma metodologia de inserção para essa malha urbana tridimensional, para que, através de mecanismos semelhantes, possa-se fazer o mesmo em diferentes contextos. As fases para conceber tal ensaio dividem-se em três: a primeira é analítica e contextual, a segunda é a de verticalização, e a terceira é a de conexão horizontal.

\subsection{Análise contextual}

Na primeira parte, é definida uma porção de quadras que agora comportar-se-ão como um único lote; aqui, foram escolhidas seis. Um dos vértices dessa área delimitada é o cruzamento da Avenida Rio Branco com a Alameda Nothmann (Fig. 05). A etapa seguinte consiste na investigação dos imóveis para definir remoções especificas (Fig. 06). 


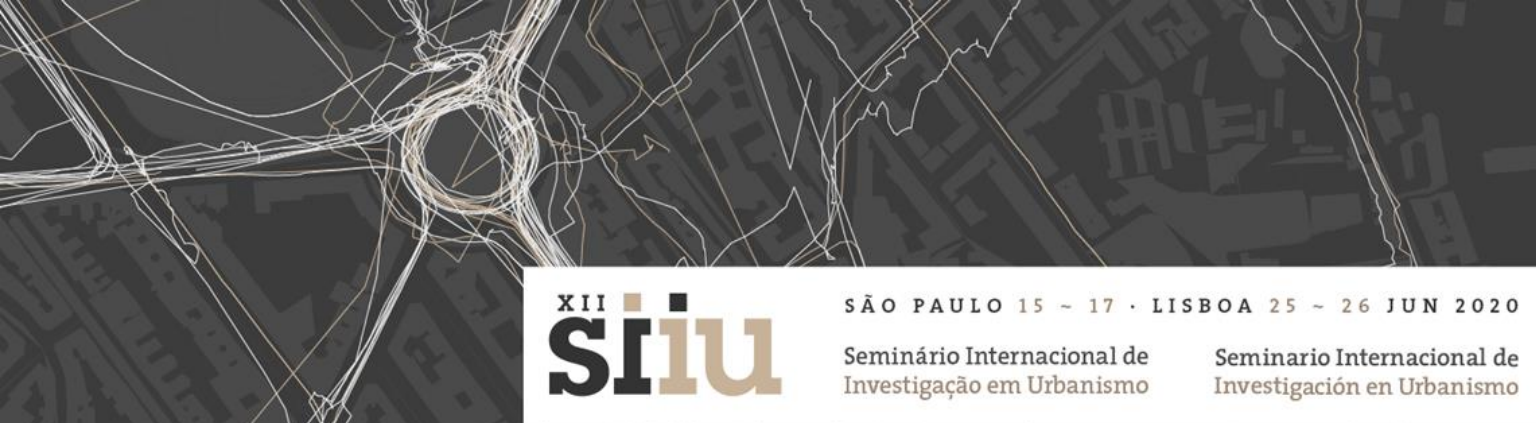

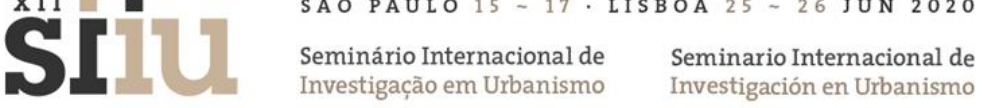

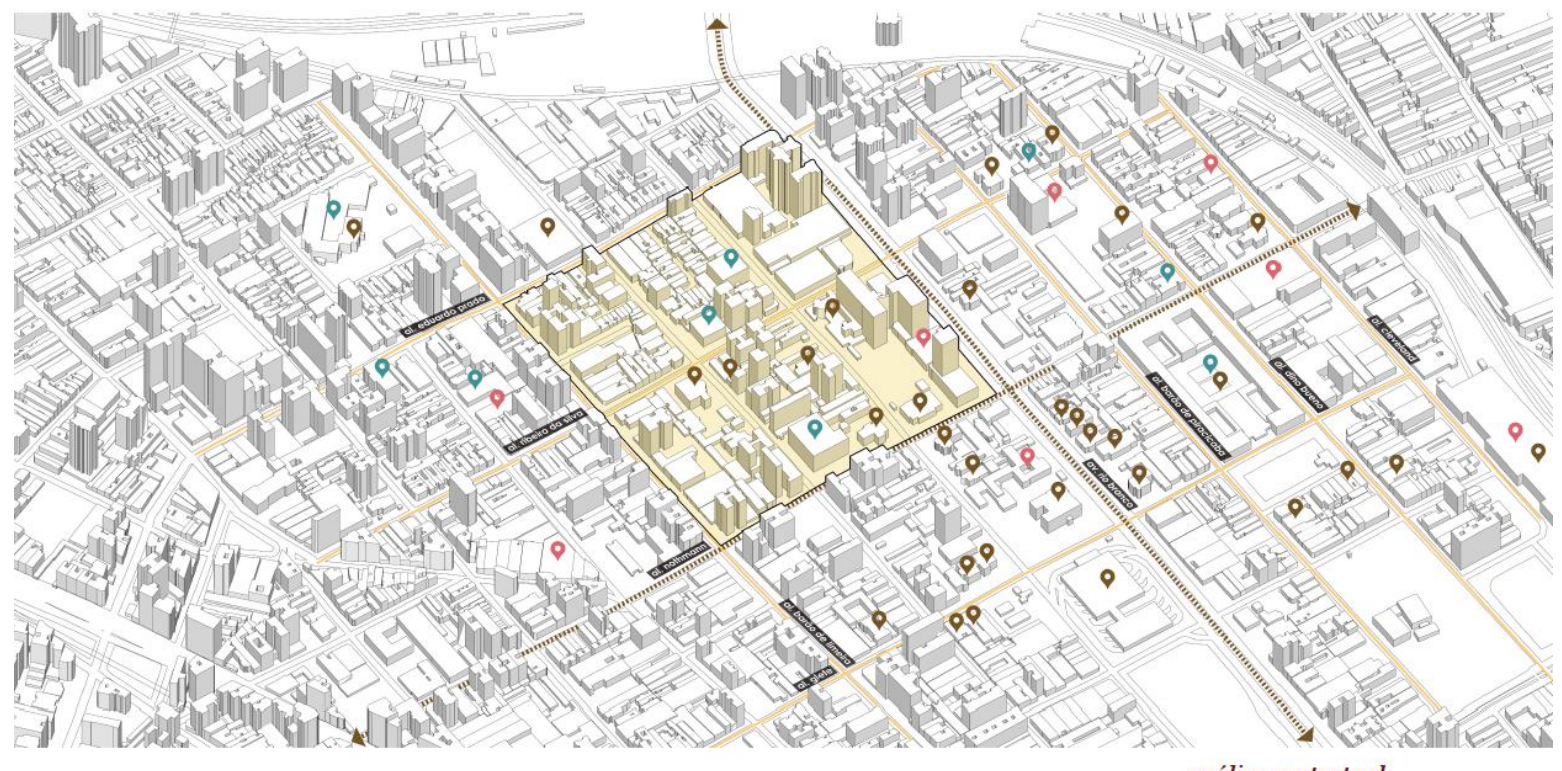

análise contextual

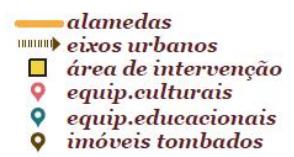

Fig. 05 Análise contextual. Elaboração própria.

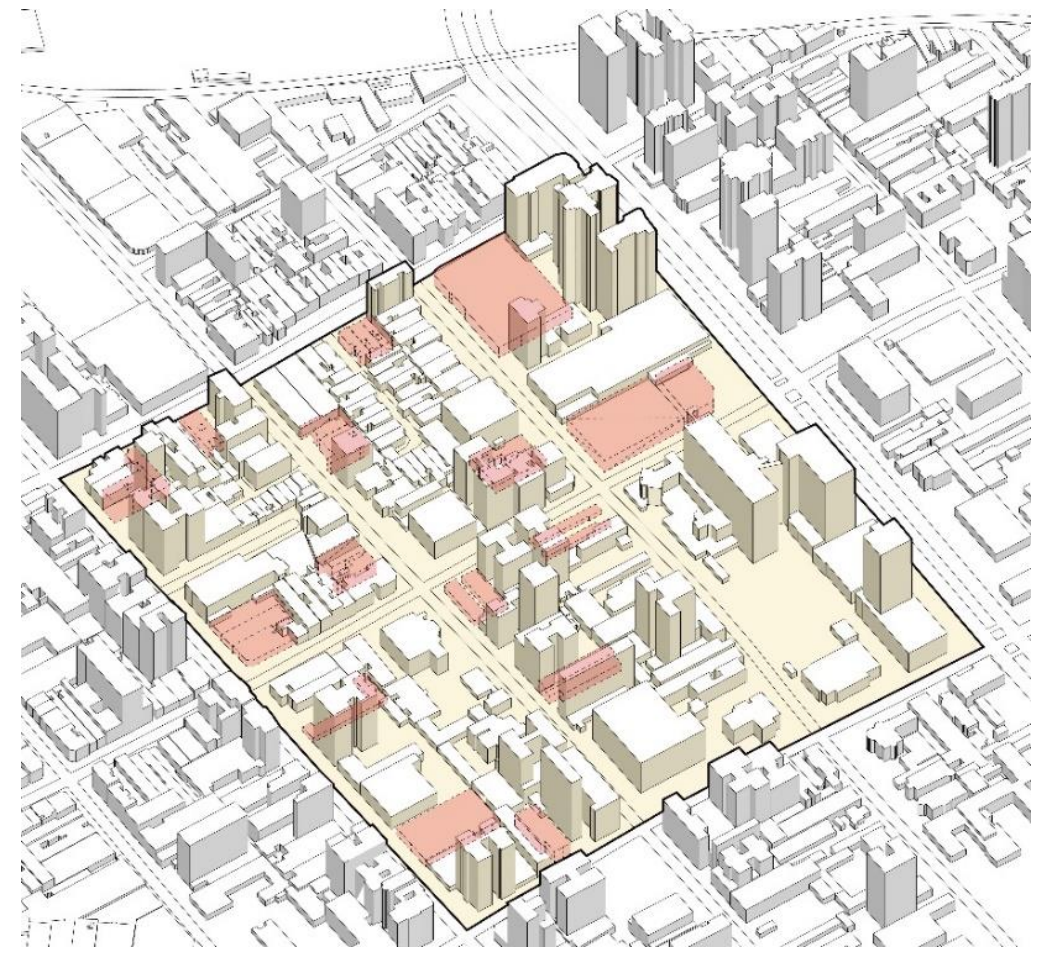

Fig. 06 Remoções específicas do conjunto. Elaboração própria. 


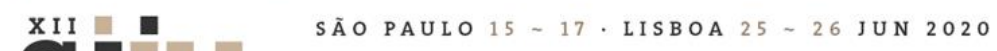

\subsection{Eixos Verticais}

Uma parcela da possível metragem quadrada a ser construída é deixada para a elaboração dos eixos verticais, que surgirão nos lotes apontados na primeira fase (Fig. 07). Foi definido um coeficiente de aproveitamento máximo para a exploração formal (CA), que no caso, baseou-se no potencial construtivo da Operação Urbana Centro, que pode chegar até 6 (CAop).

Por conter pré-existências, a área total de intervenção é definida através de uma operação matemática no qual acha-se o CA possível para construir, o Delta $(\Delta)$, através da subtração do CAop pelo CA existente $(\mathrm{CAe})$. Para isso, é necessário identificar, portanto o CA das construções existentes (CAe). Esse valor foi achado através da multiplicação da área de projeção dos edifícios (Aproj) pelo número de pavimentos dos mesmos (N). Em seguida, o valor encontrado é dividido pela área total dos lotes (At lotes). Esse resultado é então subtraído do potencial construtivo concedido pela Operação Urbana, encontrando assim o Delta.

$\mathrm{CAe}=($ Aproj $\times \mathrm{N}) /($ At lotes $)$

$\Delta=(\mathrm{CAop})-(\mathrm{CAe})$

$\Delta=\mathrm{CA}$

Para conferir os valores, encontra-se o quanto de área construída poderia ser obtida com CAop (Atop), e em seguida subtrai-se este valor pelo total de área construída das pré-existências (Atpe), achando assim área exata que se pode construir (At).

Atop $=(C A o p) \times($ At lotes $)$

$A t=($ Atop $)-($ Atpe $)$

No caso desta porção de 6 quadras:

$\mathrm{CAe}=267.000 / 87.336=3,05$

$\Delta=6-3,05=2,95=\mathrm{CA}$

2,95 é, portanto, o potencial construtivo adicional que se pode ter nas seis quadras. O próximo passo é saber o quanto poderia construir com CA 6, para conferição das metragens quadradas:

Atop $=6 \times 87.336=524.016 \mathrm{~m}^{2}$

At $=524.016-267.000=257.000 \mathrm{~m}^{2}$

Esse é o valor máximo que a estrutura poderá comportar, mas essa metragem quadrada seria alcançada com o passar do tempo, conforme a economia e as necessidades programáticas. Haveria na verdade $257.000 \mathrm{~m}^{2}$ de área apropriável, em uma nova malha urbana, agora, tridimensional. Multiplicou-se a área de construção, e quando necessário, a cidade pode recorrer a ela, e não a desapropriação de terrenos já consolidados e à demolição de construções que já carregam em si um valor arquitetônico, urbano e imagético na consciência coletiva. A memória é preservada. 


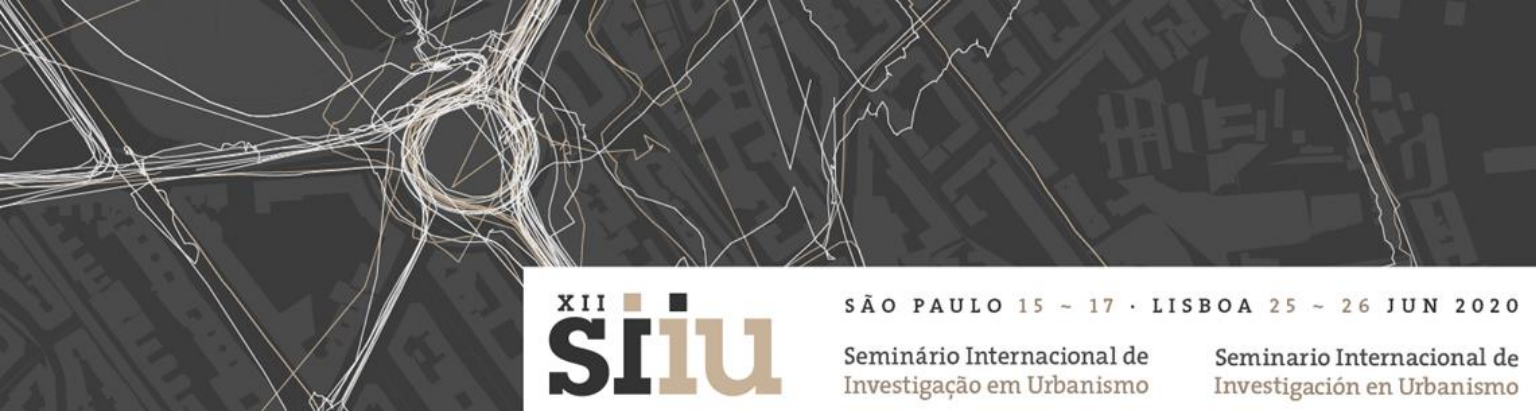

\section{$\begin{array}{ll}\text { Seminário Internacional de } & \text { Seminario Internacional de } \\ \text { Investigação em Urbanismo } & \text { Investigación en Urbanismo }\end{array}$}

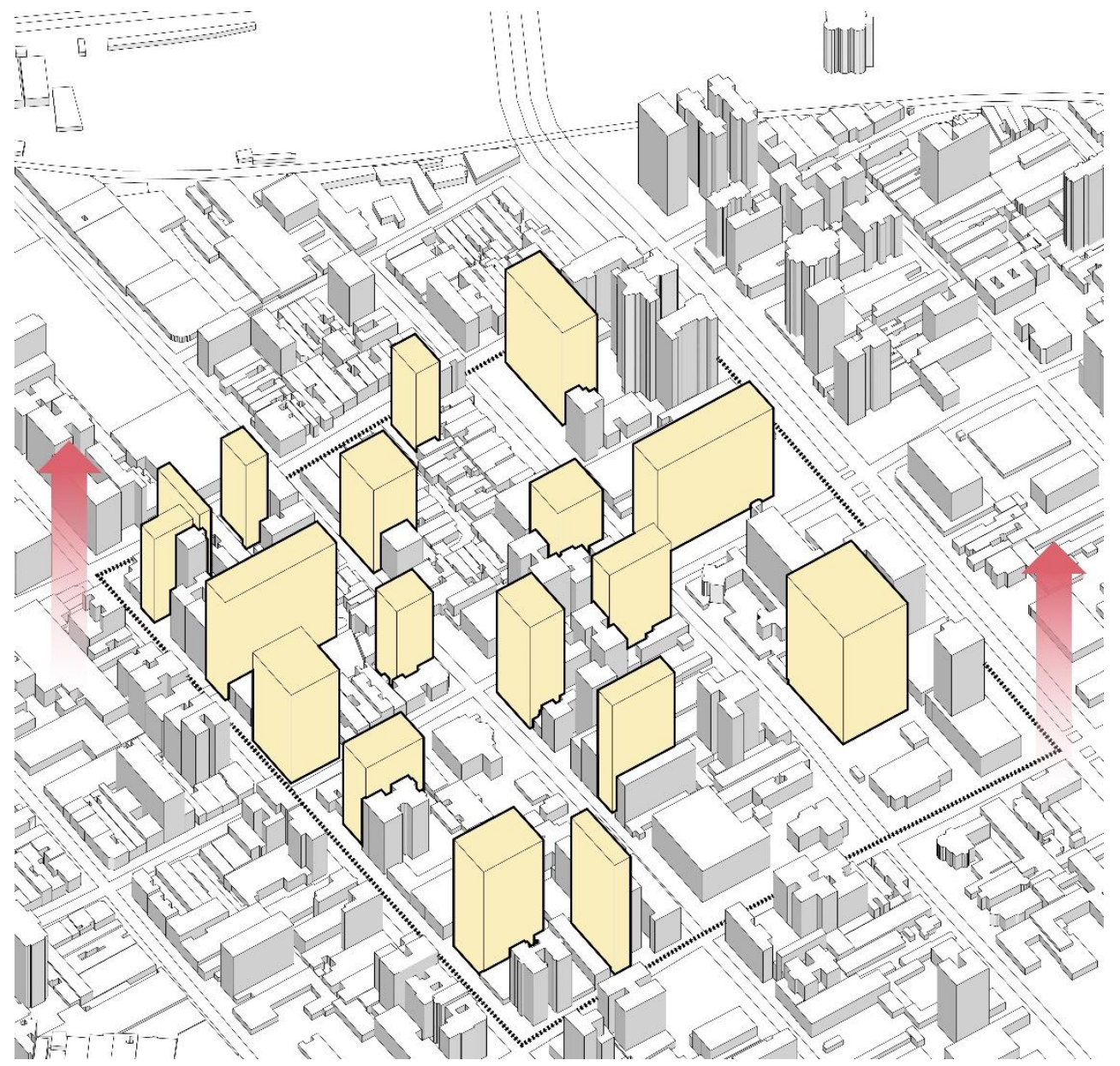

Fig. 07 Extrusões verticais. Elaboração própria.

\subsection{Eixos Horizontais}

Para a elaboração das massas que conectar-se-ão com as extrusões verticais, retoma-se o desenho bidimensional. A exploração aqui pode ser livre, dependendo do contexto. Neste caso das seis quadras, foram testadas três possibilidades: uma dupla de três, um trio de duplas, e um conjunto total, unindo-as.

Nessa parte, adota-se uma metodologia de análise espacial denominada Space Syntax, efetuada através de um software dedicado, o DeathMap (Fig. 08). Esse recurso traça eixos provenientes dos vértices das formas geométricas, que é entendido pelo sistema como uma série de poligonais. Define conexões, grau de escolha e interatividade, dentre outros parâmetros que somente o desenho, sem a intervenção humana diz. As informações são posteriormente analisadas e transformadas em decisões projetuais. (Al-Sayed, 2018). 
SÃO PAULO $15 \sim 17 \cdot$ L IS BOA $25 \sim 26$ JU N 2020
$\begin{aligned} & \text { Seminário Internacional de } \\ & \text { Investigação em Urbanismo }\end{aligned}$
$\begin{aligned} & \text { Seminario Internacional de } \\ & \text { Investigación en Urbanismo }\end{aligned}$

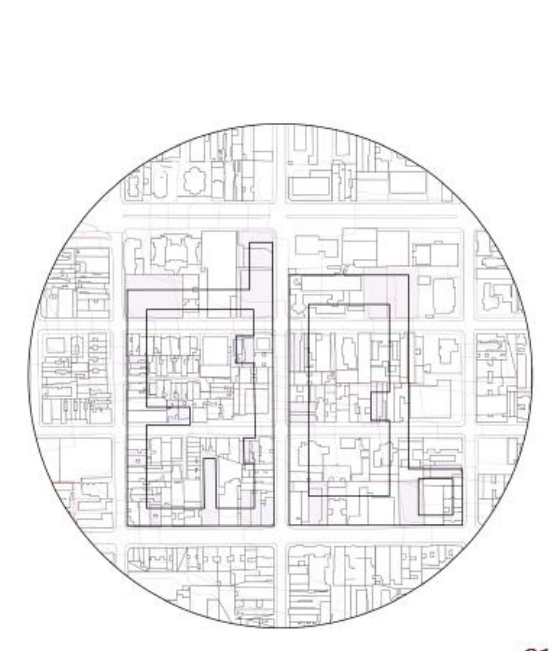

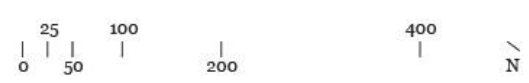

01
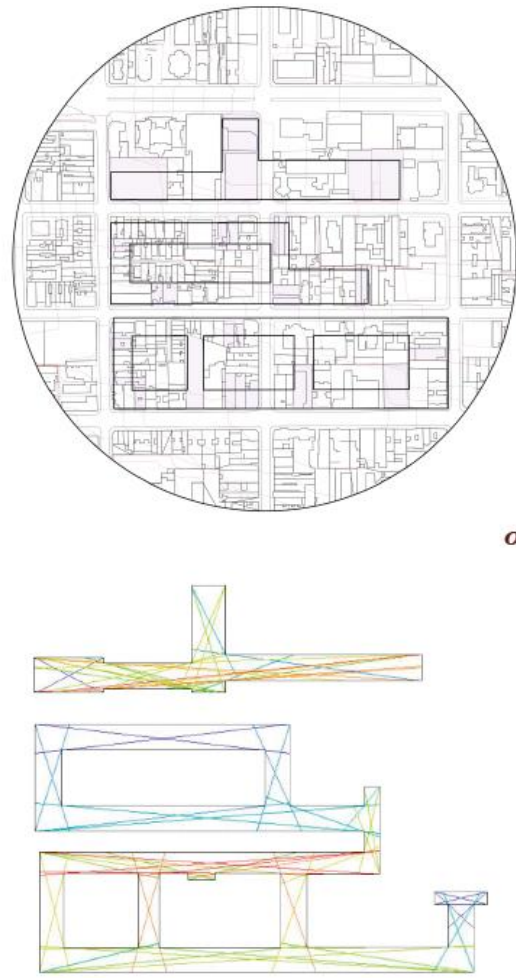

.o2 - trio; junção de 2 quadras _pontos de apoio: $3 / 6 / 9$

-quantidade de eixos: 69

_conexões (max): 22
N estudo conexões horizontais

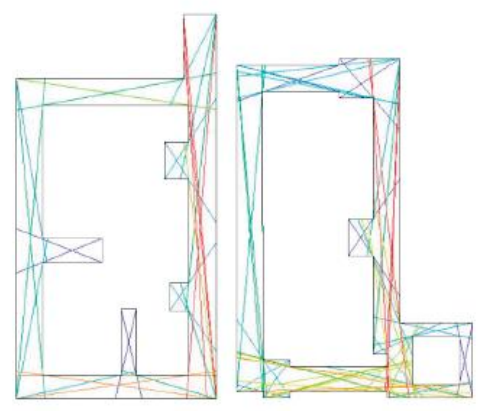

.o1 - dupla; junção de 3 quadras

_quantidade de eixos: 78

conexões (max): 37
conexões (mín): 13 o2

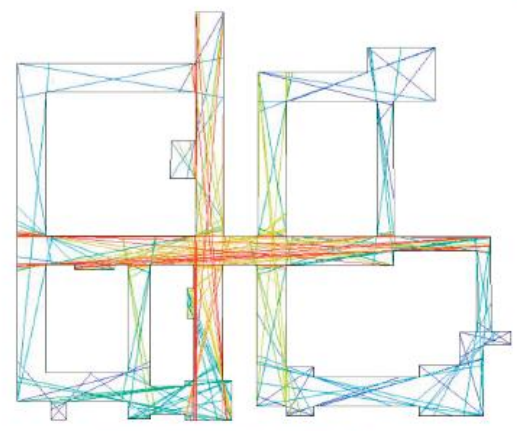

.03 - único; junção de 6 quadras

pontos de apoio: 18

quantidade de eixos: 164

_conexões (max): 91

Fig. 08 Estudo bidimensional e análise via DeathMap. Elaboração própria. 

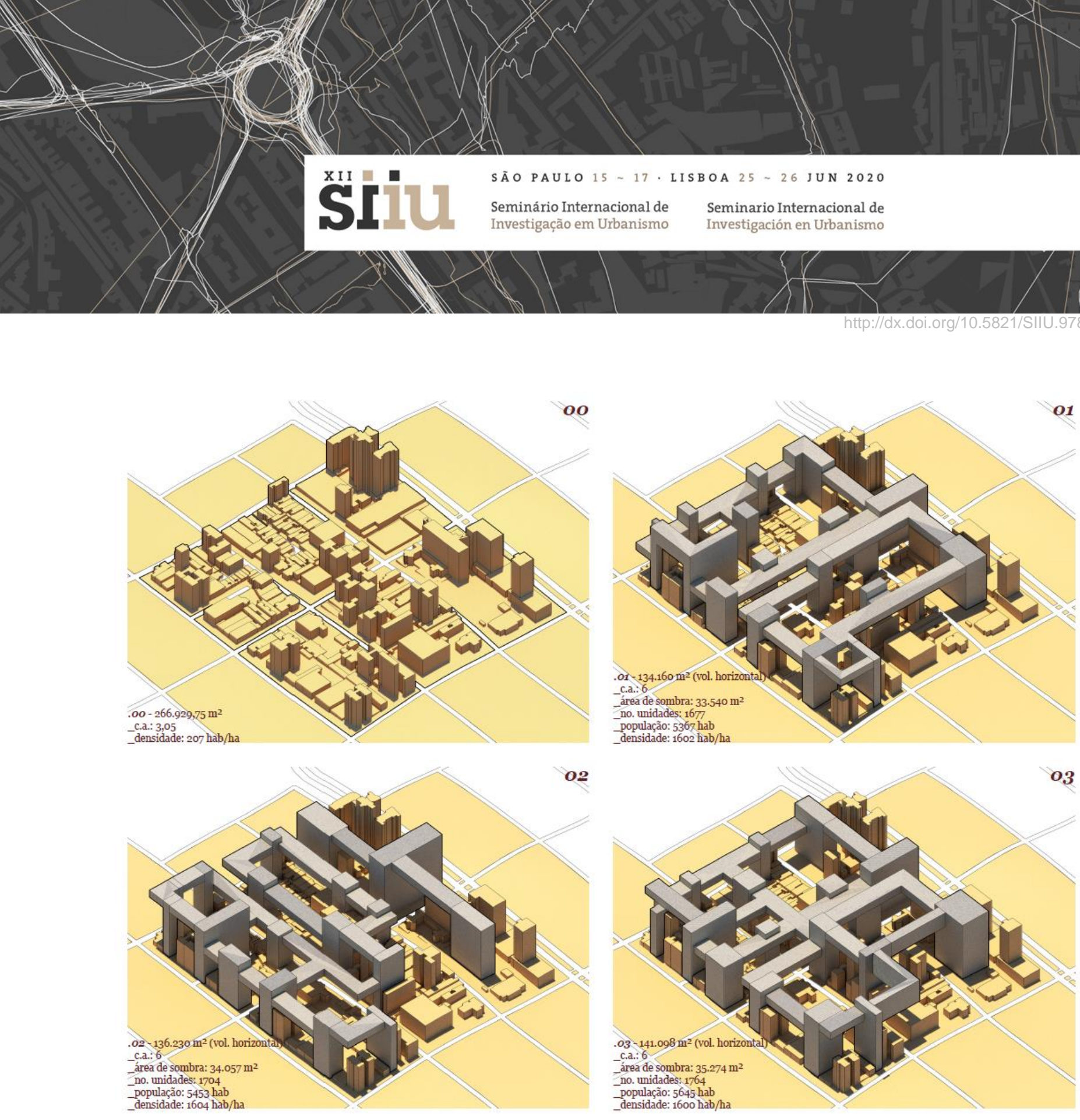

Fig. 09 Estudo volumétrico dos três modelos. Elaboração própria.

O modelo escolhido no final é uma consequência das análises volumétricas e espaciais (Fig 09). Como exercício de adensamento máximo, essa opção é a que possibilita maior número de unidades residenciais e maior população: 5645 habitantes. Curiosamente é a de menor densidade, se comparado o dado bruto (1600 hab/ha), justamente devido à sua área, que é um pouco mais elevada. Quando analisados os mapas axiais, o modelo 03 é o que oferece a maior quantidade de eixos e conexões, evidenciando a maior potencialidade do desenho. (Fig. 10) 


\section{SÃOPAULO15 $\quad 17 \cdot$ LISBOA $25 \sim 26$ JUN 2020}

Seminário Internacional de Investigação em Urbanismo

Seminario Internacional de Investigación en Urbanismo

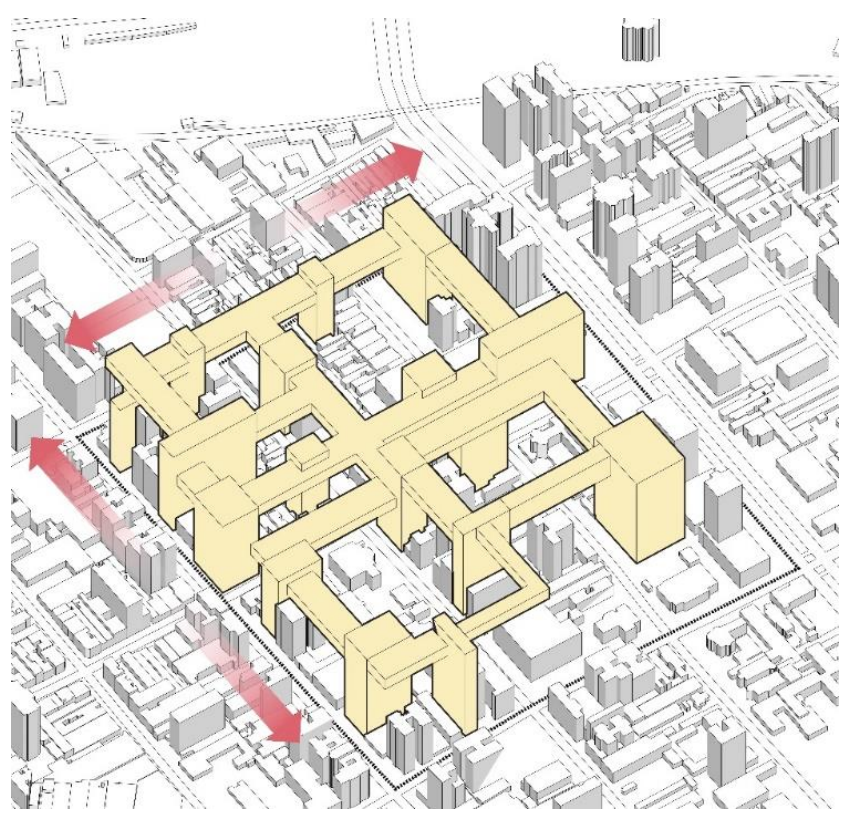

Fig. 10 Conexões horizontais com modelo 03. Elaboração própria.

\subsubsection{Estrutura}

Para transformar a massa conceitual em edificação habitável, lança-se mão de um partido estrutural modular. A solução encontrada foi a aplicação de uma malha estrutural tridimensional, constituída por um sistema construtivo pré-fabricado, cujo material de preferência é o aço.

A malha é definida sob uma dimensão fixa, de 5 até 8 metros (Fig. 11). Esse intervalo é o ideal pois possibilita espaços diversos, independente da demanda. Os perfis metálicos não possuem dimensões exageradas, pelo contrário, as partes se diluem no todo, e quando trabalham em conjunto, podem vencer grandes vãos. 


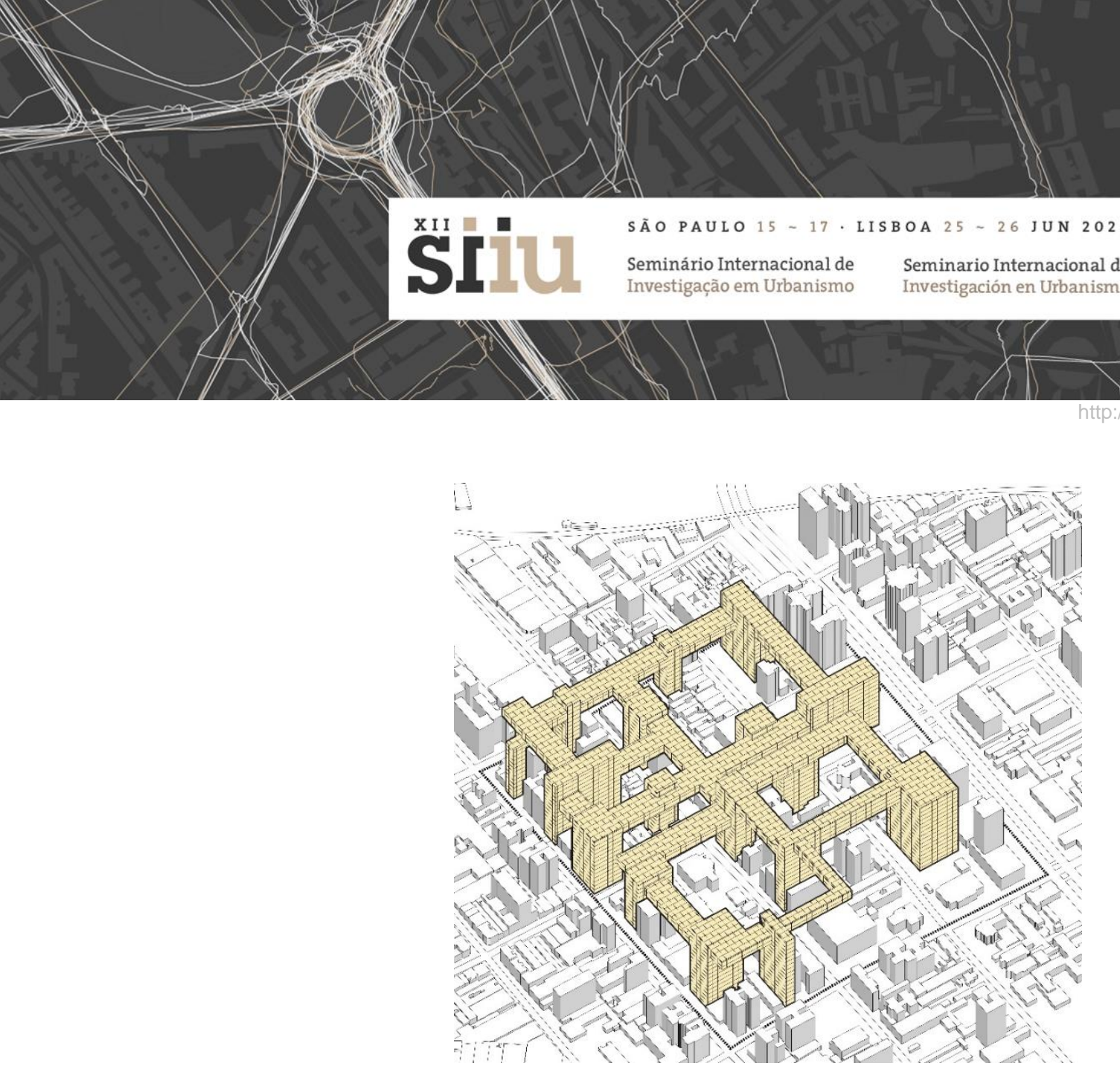

Fig. 11 Malha estrutural. Elaboração própria.

\subsubsection{Fragmentação}

A massa total é dissolvida de acordo as necessidades programáticas. Não é responsabilidade desse estudo definir o complexo todo, da mesma maneira que não se projeta edifícios de toda uma área que é concebida em um projeto urbano tradicional, apenas suas massas e volumes. As intenções são de gerar diretrizes de ocupação através do programa. A porosidade volumétrica está em função do uso (Fig. 12). É definido que atividades cotidianas são aquelas cuja tradução na arquitetura poderia flertar mais com vazios e transparências. Já do outro lado do espectro, encontram-se os programas de infraestrutura e residenciais, cuja necessidade de privacidade e estanqueidade acarretam um maior número de fechamentos. Pode-se também gerar tipologias de ocupação através do contexto imediato (Fig. 14). 
SÃO PAULO $15 \sim 17 \cdot$ L IS BOA $25 \sim 26$ JUN 2020
$\begin{aligned} & \text { Seminário Internacional de } \\ & \text { Investigação em Urbanismo }\end{aligned}$

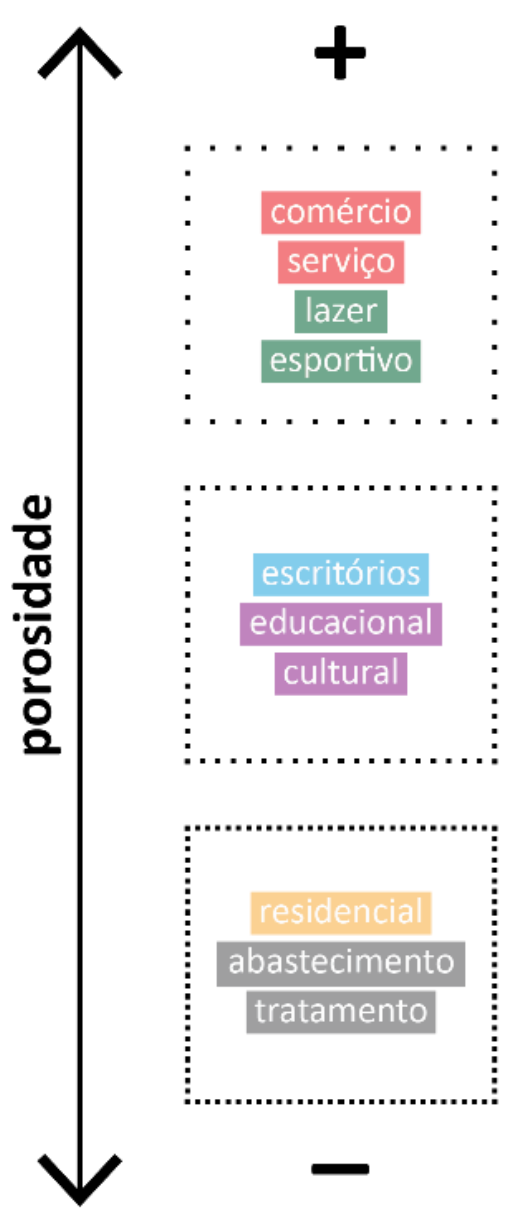

Fig. 12 Diagrama de porosidade volumétrica. Elaboração própria. 


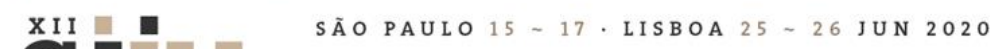 \\ SIIUl $=$}

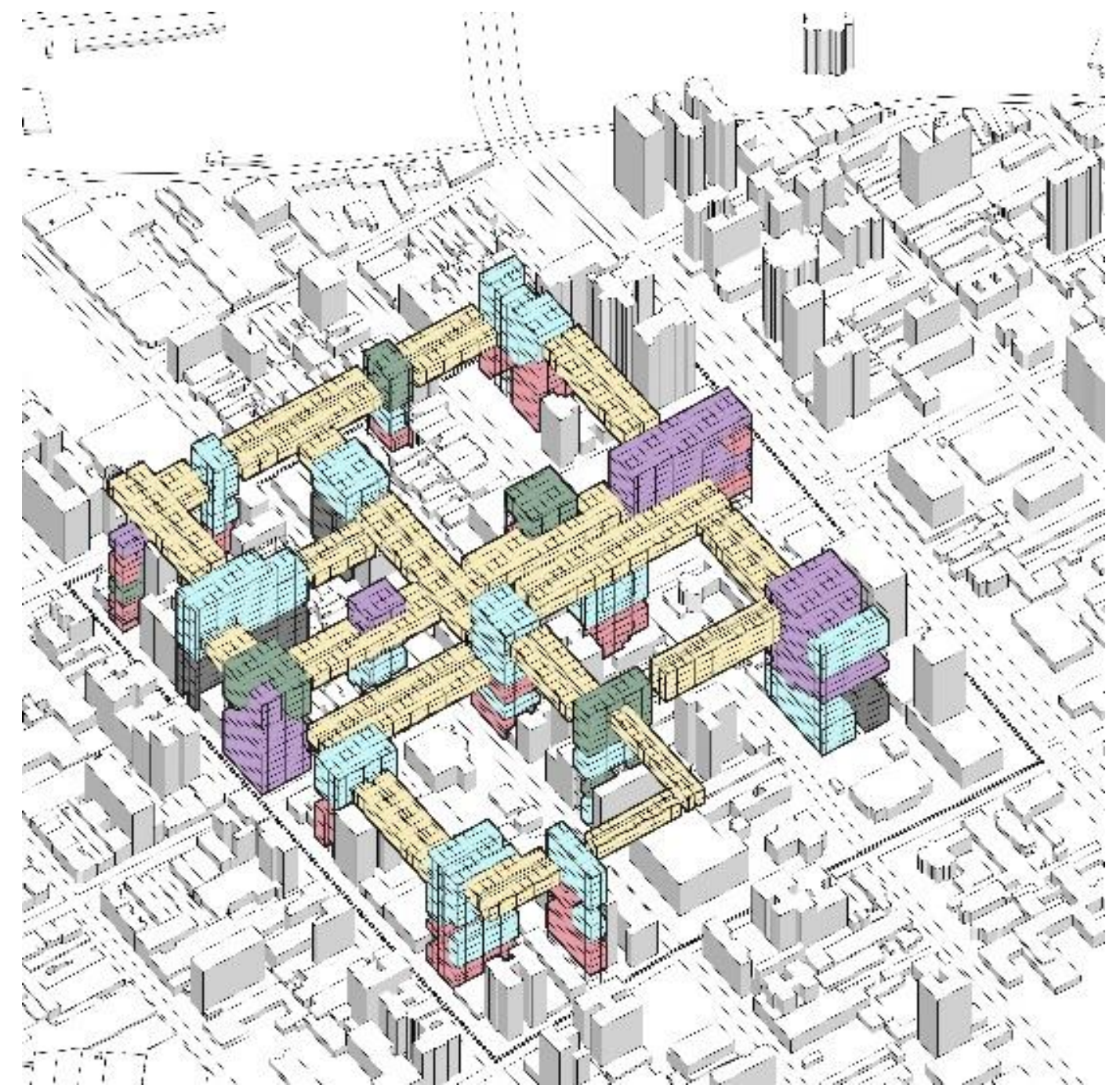

Fig. 13 Porosidade aplicada ao programa. Elaboração própria. 


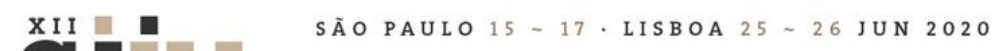

Seminário Internacional de Investigação em Urbanismo

Seminario Internacional de Investigación en Urbanismo

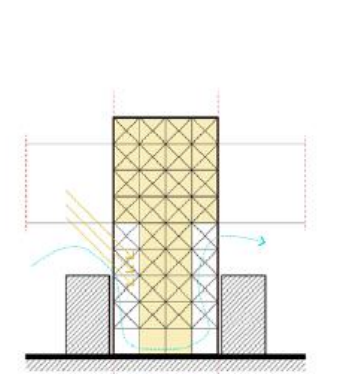

baixo gabarito

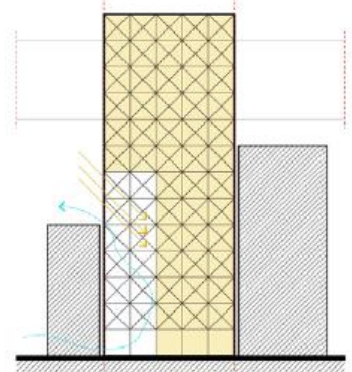

gabaritos variados_A

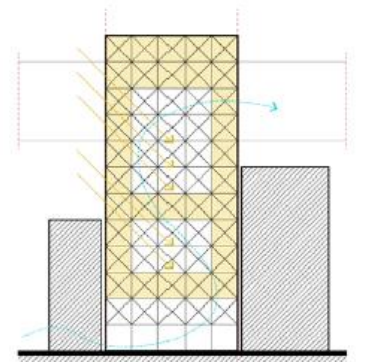

gabaritos variados_B

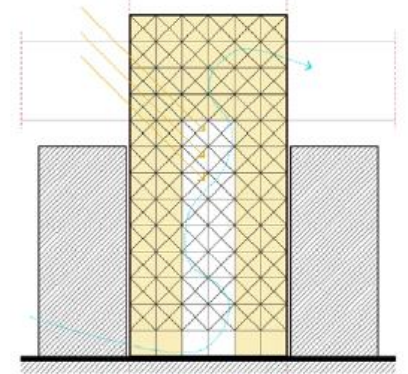

alto gabarito

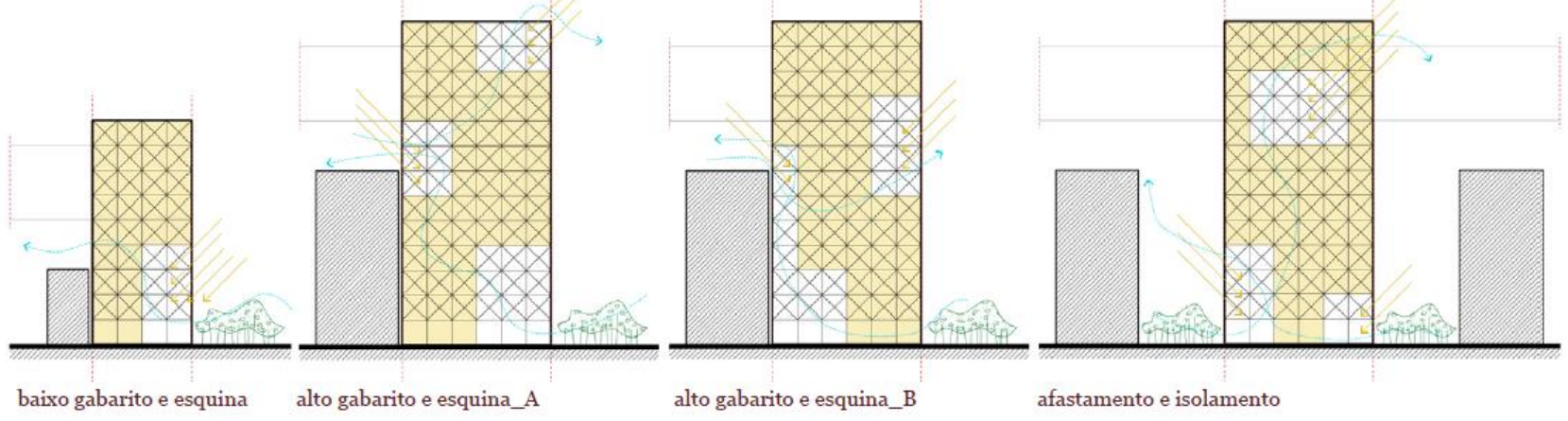

Fig. 14 Tipologias de ocupação através de contexto imediato. Elaboração própria.

\subsubsection{Cota Pública Elevada}

No topo, e como contrapartida das ocupações da nova malha, surge uma nova rua paralela conectando quadras inteiras e intensificando as dinâmicas internas do projeto, de acesso livre. Uma espécie de recuo no eixo Z, retornando de volta à cidade um espaço para que ela ocorra, da mesma maneira que as construções tradicionais devem respeitar recuos frontais; a estratégia é a mesma, só se acrescentou outra dimensão, a vertical (Fig. 15). 


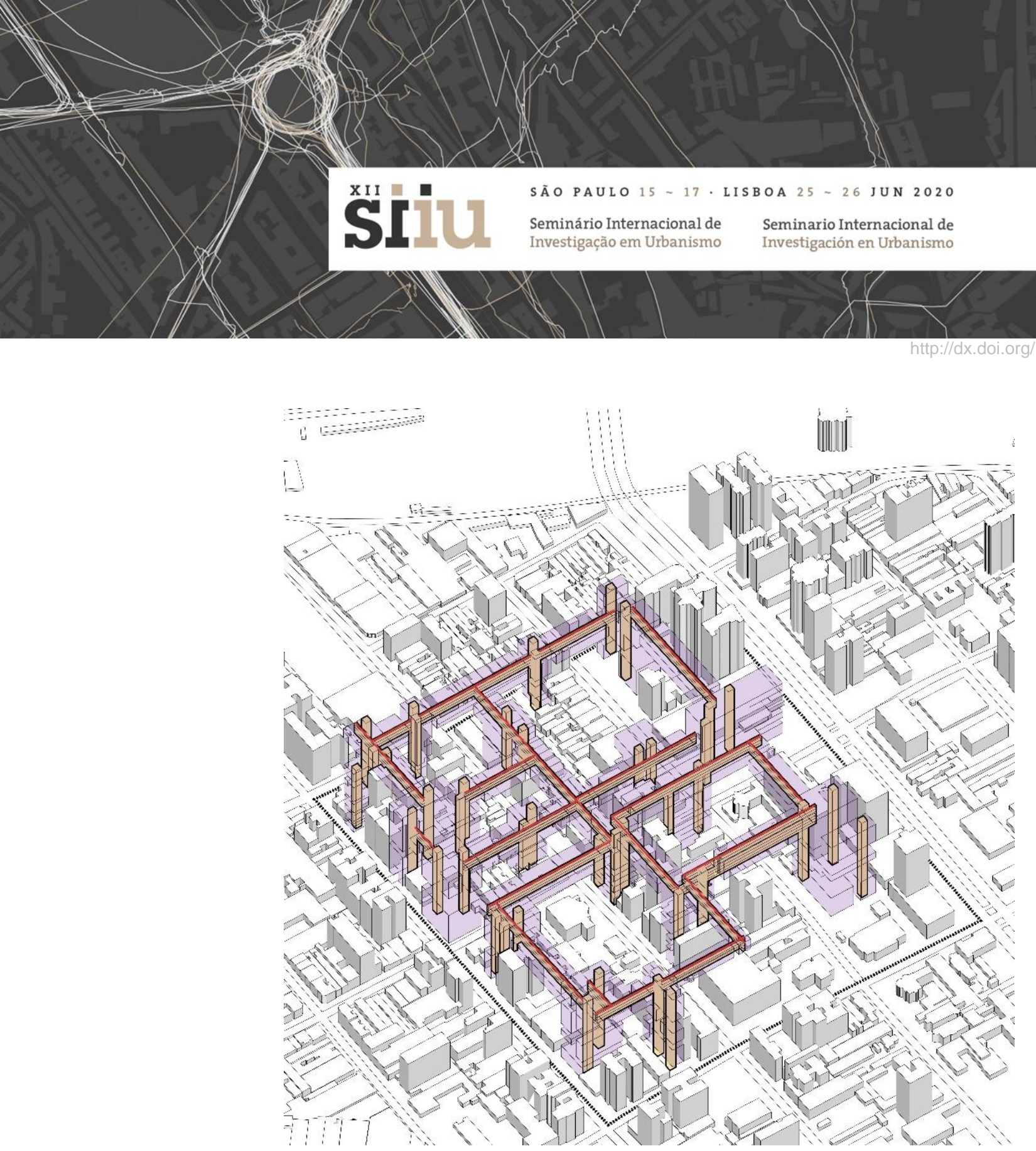

Fig. 15 Cota pública elevada. Elaboração própria.

Certamente há diversas maneiras de ocupar a cota elevada. Poderia ser uma alameda de comércios e serviços, coberta; pode ser também uma área livre e aberta, aos moldes de um parque linear, com áreas para prática esportiva e estar público. Há também um meio termo, no qual a natureza espacial assemelha-se mais a um boulevard, com pequenas áreas de encontro, mirantes e comércios surgindo em sequência.

Essa superestrutura se comportaria como uma continuação da malha urbana, porém agora tridimensional. Essa retícula teria as mesmas características que as retículas viárias urbanas. Podem ser compradas, negociadas e alugadas. Nela se encontrariam quaisquer programas que a cidade possa demandar, sendo preenchida conforme o tempo e as necessidades. Um plano urbano de 3 eixos. (Fig. 16,17,18,19) 


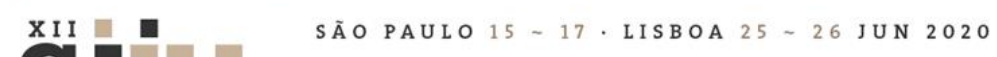

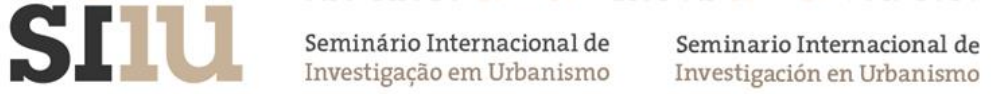

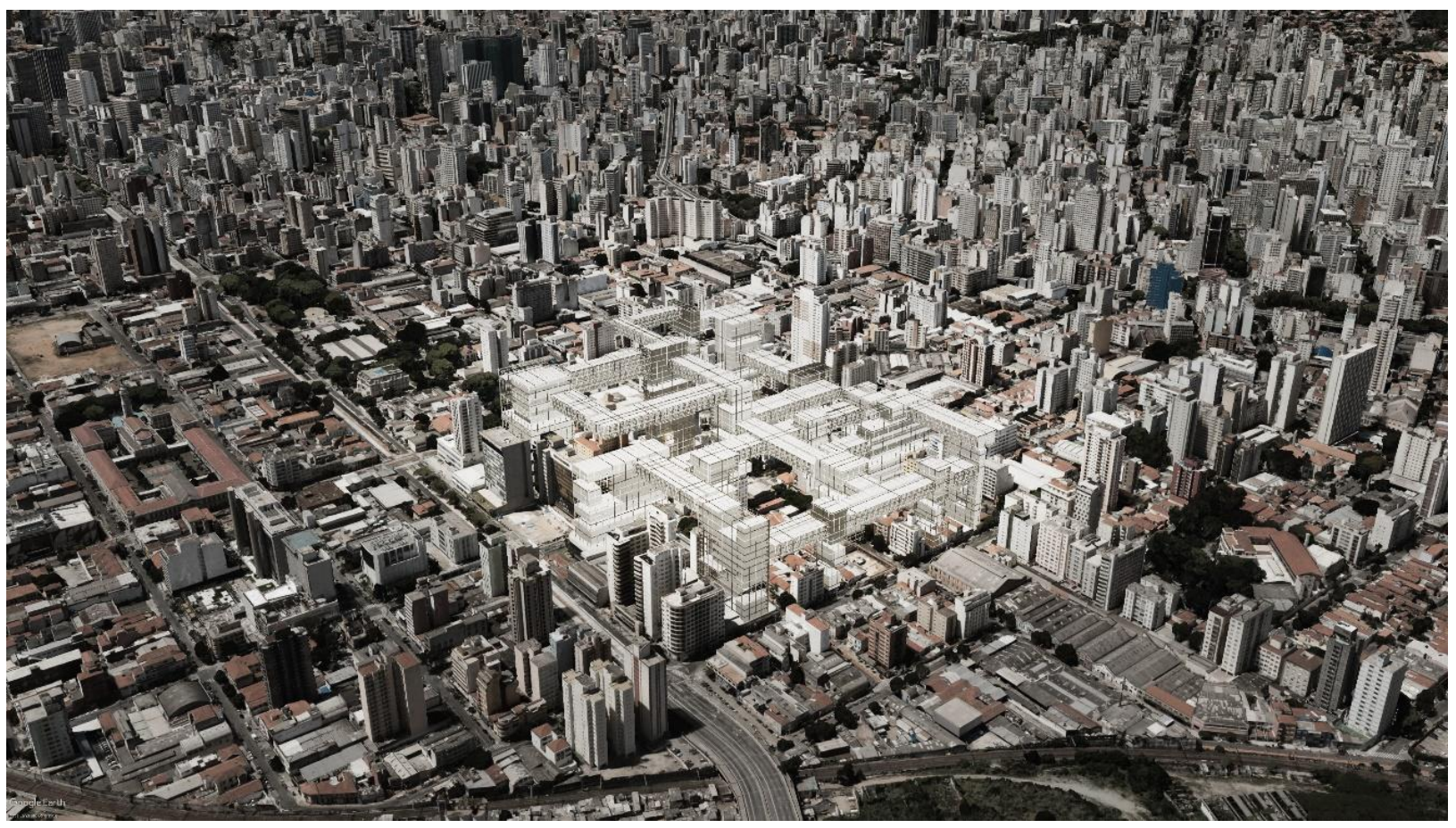

Fig. 16 Colagem representando o conjunto no contexto. Elaboração própria

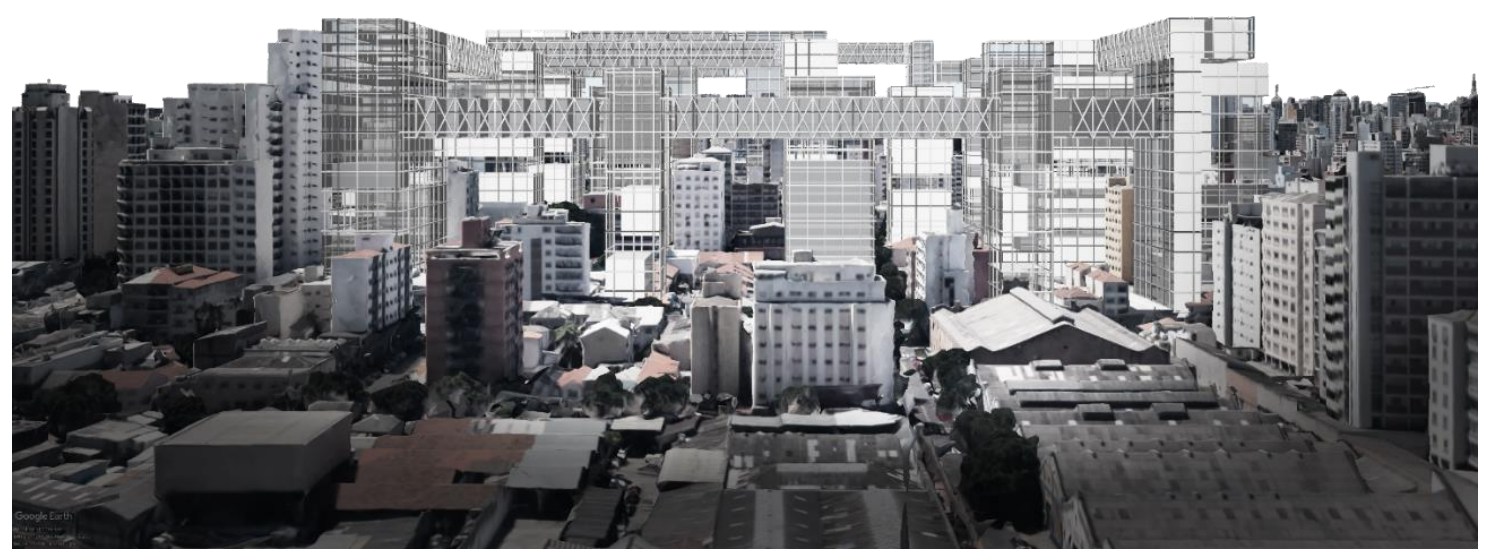

Fig. 17 Colagem representando o conjunto no contexto. Elaboração própria 


\section{SÃO PAULO15 17 LISBOA $25 \sim 26$ JUN 2020

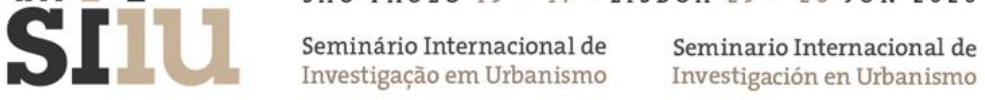

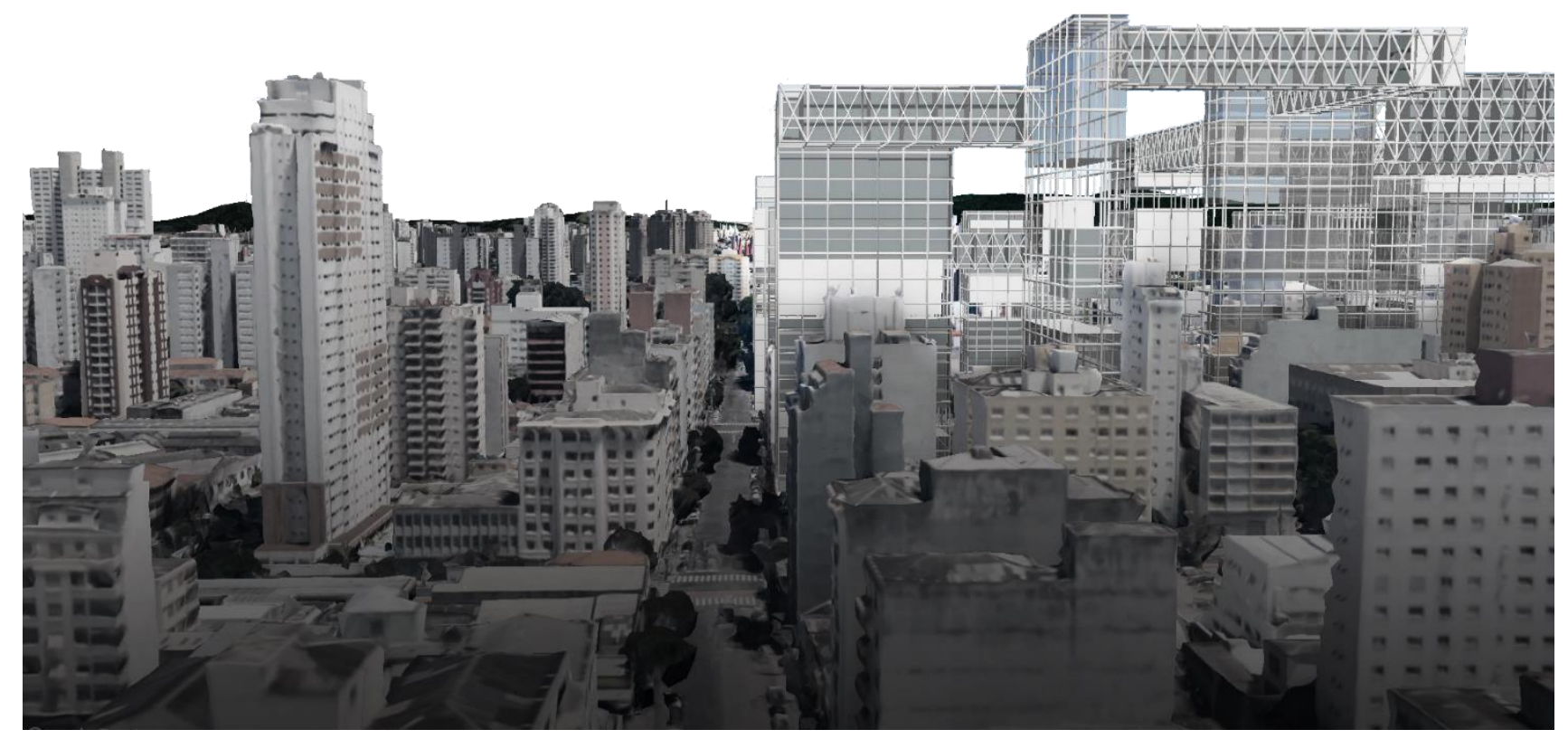

Fig. 18 Colagem representando o conjunto no contexto. Elaboração própria

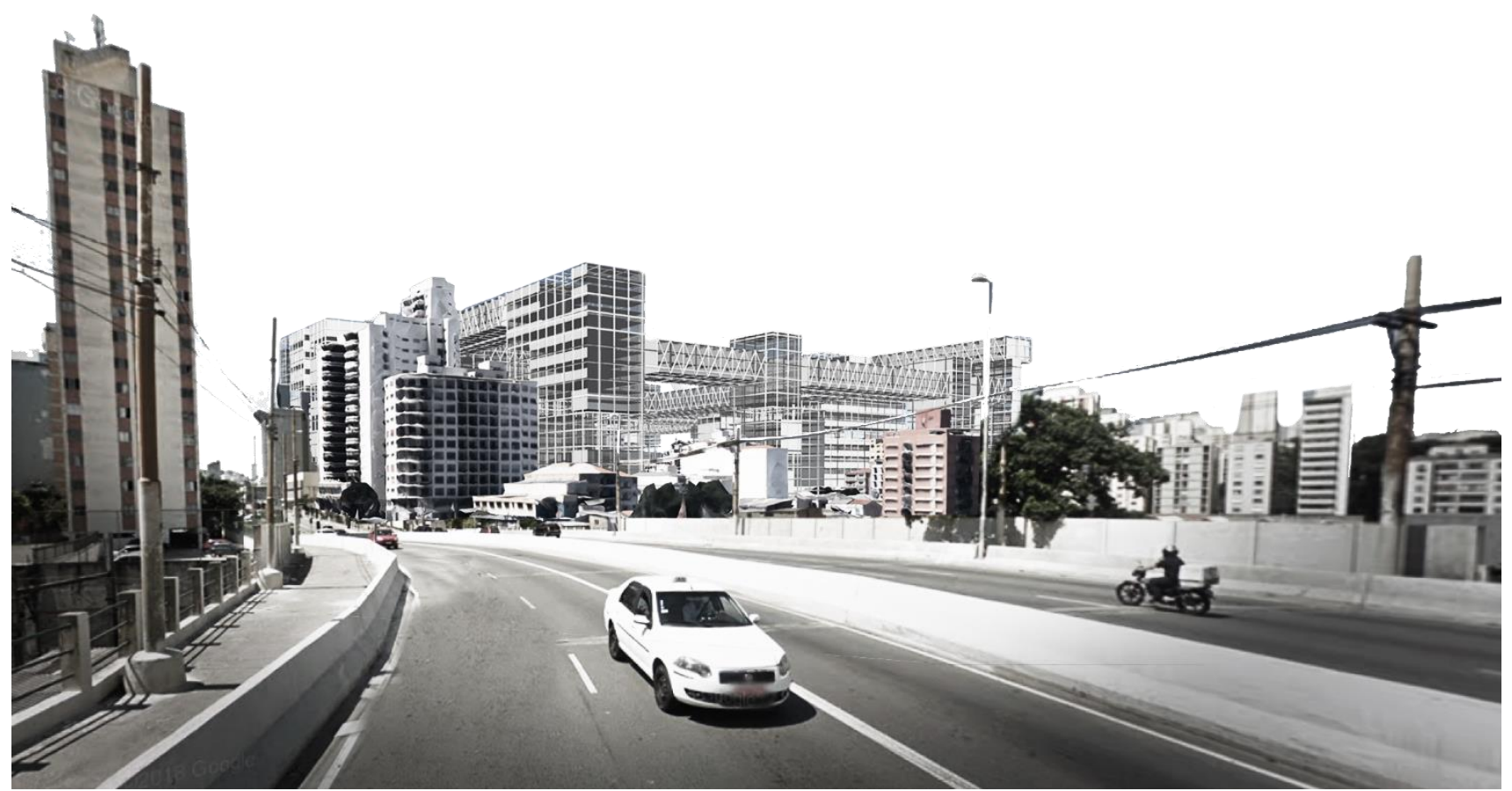

Fig. 19 Colagem representando o conjunto no contexto. Elaboração própria 


\section{SÃOPAULO15 $17 \cdot$ LISBOA $25 \sim 26$ JUN 2020}

\section{Conclusão}

A intenção deste estudo é fomentar o hiper adensamento e a ocupação metropolitana em conjunto com seu tecido histórico e sua preservação. A revisitação dos utópicos ensaios do século XX apresenta-se como uma ferramenta ao arquiteto urbanista para auxiliar nos desafios da cidade do futuro, que já se faz no presente. As soluções que se buscam para as metrópoles, por vezes, não são as ideais, mas sim as necessárias. E é sob essa ótica que é desenvolvido este ensaio. Uma espécie de devaneio, uma hipótese em seu real significado, um cenário que pode vir a ser, devido as loucas demandas de uma cidade global cuja a morfologia urbana é então alterada e caracterizada.

A felicidade do estudo encontra-se no fato de ser flexível em relação ao contexto, diferentemente do repertório utópico aqui apresentado. Buscou-se criar uma metodologia de inserção, pois dessa maneira, nunca nenhuma intervenção será igual à outra. Sucintamente, são apenas lotes tridimensionais, unidades urbanas mínimas que agora avançam sobre o céu, trazem unidade ao conjunto, preservando o maior patrimônio urbano: a própria cidade.

Em um contexto metropolitano, onde diferentes culturas e usuários se mesclam ativamente, no qual o fluxo de informações e comunicações não cessam e se transformam constantemente, elevando-se a enésima potência conforme a cultura e a sociedade englobam a tecnologia e vice-versa, gerando simultanemante novas potencialidades e deficiências através de suas condicionantes, essa ideia torna se até um tanto tímida.

O potencial formal urbano é muito maior do que imaginamos.

\section{Bibliografia}

AL-SAYED, K. (2018). Space Syntax Methodolgy, a teaching guide for the Space Syntax Course. Londres: Bartllett School of Architecture, UCL.

CORREA, F. (2018). São Paulo, Uma Biografia Gráfica [tradução Giovana Boselli]. Texas: University of Texas Press; São Paulo: Romano Guerra Editora.

BARDA, M. (2009). Espaço (Meta)Vernacular na Cidade Contemporânea. São Paulo: Perspectiva.

HARARI, Y. N. (2016). Sapiens, Uma breve história da humanidade [tradução Janaína Marcoantonio]. Porto Alegre: L\&PM.

KOOLHAS, R. (1972). Delirious New York. A Retroactive Manifesto for Manhattan. Nova lorque: The Monacelli Press.

LORES, R. J. São Paulo nas alturas. A revolução modernista da arquitetura e do mercado imobiliário nos anos de 1950 e 1960. São Paulo: Três Estrelas.

MARTIN, L. (1972). The Grid as Generator, in Urban Space Structure. Cambridge: Cambridge University Press.

MOURA, R., BRANCO, M. L. G. C., FIRKOWSKI, O. L. C. F. (2005). Movimento pendular e perspectivas de pesquisas em aglomerados urbanos. São Paulo: Perspectiva. vol.19, no.4. 


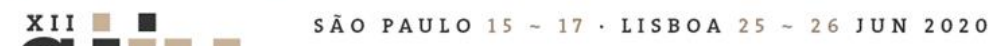

PER, A. F., MOZAS, J., ARPA J. (2016). 50 Urban Blocks. Barcelona: a+t research group - (2015). Why Density? Debunking The Myth Of The Cubic Watermelon. Barcelona: a+t research group.

RIBEIRO, D. M. M. (2017). Arquitetura Radical em Disputa: discussões sobre utopias entre o fim dos anos 1950 e início dos anos 1970. Revista UFMG. Belo Horizonte, v. 24, n. 1 e 2, 176-203.

ROGERS, R. GUMUCHDJIAN, P. (2016). Cidades para um Pequeno Planeta. São Paulo: Gustavo Gili. ROLNIK, R. (2013). São Paulo. São Paulo: Publifolha.

ROSSI, A. (1978). L'architettura della città. Milão: Clup.

TOLEDO, B. L. (1981). São Paulo, três cidades em um século. São Paulo: Duas Cidades.

YOOS, J., JAMES, V. (2016). Parallel Cities: the Multilevel Metropolis. Minneapolis: Walker Art Center.

Processo de Tombamento de Campos Elíseos - Proc. SC 24.506/86 CONDEPHAAT - Conselho de Defesa do Patrimônio Histórico, Arqueológico, Artístico e Turístico do Estado (1986). 